\title{
Financial Ratio Analysis to Predict Financial Distress on Property and Real Estate Company listed in Indonesia Stock Exchange
}

\author{
Imas Nurani Islami \\ imas.nurani@president.ac.id \\ Accounting Study Program, Faculty of Business \\ Universitas Presiden, Cikarang, Indonesia \\ William Rio \\ wriosiahaan@yahoo.com \\ Accounting Study Program, Faculty of Business \\ Universitas Presiden, Cikarang, Indonesia
}

\begin{abstract}
This study aims to prove the ability of financial ratios in measuring financial distress. As is known that the start of the number of new companies that compete in order to achieve corporate goals, even more national companies that want to compete with foreign companies. On this basis, researchers attempt to prove the probability of occurring financial distress by using several financial ratios, especially large companies such as property and real estate firms. The financial ratios used in this study are current ratio, debt ratio, return on equity ratio, and capitalization ratio. With the type of research that is quantitative, the population that has been used in this study are property and real estate companies listed on the Indonesia Stock Exchange period 2012-2016. -. The sample obtained is a company that continuously publish its financial report within five years. According to the results of research that has been done, the ratio is able to measure the possibility of financial distress in property companies and real estate is the current ratio, debt ratio, and return on equity ratio. While the ratio is not able to measure the likelihood of occurrence of financial distress is capitalization ratio.
\end{abstract}

Keywords: Financial Distress, Current Ratio, Debt Ratio, Return on Equity Ratio, Capitalization Ratio

\begin{abstract}
Abstrak
Penelitian ini bertujuan untuk membuktikan kemampuan rasio keuangan dalam mengukur financial distress. Seperti yang diketahui bahwa mulai banyaknya perusahaan baru yang berkompetisi demi mencapai tujuan perusahaan, terlebih lagi perusahaan nasional yang ingin bersaing dengan perusahaan asing. Atas dasar inilah, peneliti berupaya untuk membuktikan probabilitas terjadinya financial distress dengan menggunakan beberapa rasio keuangan, khususnya perusahaan-perusahaan besar seperti perusahaan properti dan real estate. Rasio keuangan yang digunakan dalam penelitian ini adalah current ratio, debt ratio, return on equity ratio, dan capitalization ratio. Dengan jenis penelitian yang bersifat kuantitatif, populasi yang telah digunakan pada penelitian ini adalah perusahaan properti dan real estate yang terdaftar pada Bursa Efek Indonesia periode 2012-2016. Berdasarkan metode yang digunakan, yaitu purposive sampling, sampel yang sudah memenuhi kriteria pada penelitian ini sebanyak 34 perusahaan dengan total laporan keuangan sebanyak 170
\end{abstract}


data tetapi hanya 159 data yang dapat digunakan dikarenakan adanya data outlier. Sampel yang diperoleh adalah perusahaan yang secara terus-menerus menerbitkan laporan keuangannya dalam kurun waktu lima tahun. Menurut hasil penelitian yang telah dilakukan, rasio yang mampu mengukur kemungkinan terjadinya financial distress pada perusahaan properti dan real estate adalah current ratio, debt ratio, dan return on equity ratio. Sedangkan rasio yang tidak mampu mengukur kemungkinan terjadinya financial distress adalah capitalization ratio.

Kata kunci: Financial Distress, Current Ratio, Debt Ratio, Returns on Equity Ratio, Capitalization Ratio

\section{INTRODUCTION}

Unstable economic conditions in Indonesia can lead to a high risk for companies experiencing financial difficulties. One reason is the imbalance between the company's assets and the company's receivables to the creditor. Some companies try to cope not to face financial difficulties by borrowing, merging, or even choosing to close their business. The economic condition of this company is called financial distress. Karl (2002) argues that financial distress is a long-term process that negatively affects the capital structure, investment policy and the viability of a company (Edwards et al., 2017). Some factors that can cause financial distress, for example: the high interest rates imposed on the loan, the inhibition of cash flow within the company, the difficulty in lending to creditors (Edwards et al., 2017). Financial distress can be seen through the company's financial statements. According to IAI (2002), financial statements are part of a very complete financial report process, consisting of balance sheet, income statement, statement of changes in financial position (presented in various ways, ie cash or fund statement). Financial statements can be the basis of measuring the financial distress of a company through the analysis of financial statements by using financial ratios. Financial ratio is one form of accounting information in measuring the performance appraisal process of the company, so that the company's financial condition can be disclosed through financial ratios in the period specified. In this study the authors will use several ratios, namely: current ratio, debt ratio, return on equity ratio, and capitalization ratio. Based on these four ratios, the authors will examine how the influence of financial ratios in predicting financial distress on property and real estate firms listed on the Indonesia Stock Exchange period 2012-2016. The purpose of this study is to explain how the influence of selected financial ratios in predicting financial distress on property and real estate companies listed on the Indonesia Stock Exchange period 2012-2016.

\section{LITERATURE REVIEW}

\section{Financial Distress}

Financial distress is a situation that the company's cash flow is inadequate to pay off current liabilities (such as accounts payable or interest expense) and the company is forced to take corrective action (Hapsari, 2012). Hanafi and Halim (2007) said that financial distress is illustrated by two extremes of short-to-insolvable liquidity shortfalls. Short-term financial difficulties are usually short-term, but may progress to more severe. Indicators of financial difficulties can be seen from the analysis of cash flow, financial statements, and analysis of corporate strategy. Based on the above two definitions, the authors conclude that financial distress is a condition in which a company can not repay its obligations to creditors caused by 
financial difficulties in the short and long term.

\section{Financial Ratios}

Financial ratio analysis is one way in measuring and analyzing a company's performance based on financial statements. Harahap and Sofyan (2008) said that the financial ratio is the number obtained from the comparison of a financial statement post with another post that has a relevant and significant relationship.

\section{Current ratio}

Current ratio is included in the liquidity ratio. Sawir (2003) says that current ratio is the most commonly used measure to know the ability to meet short-term liabilities, since this ratio indicates how far the demands of short-term creditors are met by assets that are estimated to be cash in the same period. Sutrisno (2012) said that the current ratio is the ratio that compares the current assets owned by the company with short-term debt. Current assets include accounts receivable, cash, inventory, and other current assets. Current ratio is a commonly used measure of short-term solvency and the ability of a firm to meet its debt requirements when it matures (Fahmi, 2011).

Hypothesis 1: Current ratio can predict financial distress.

\section{Debt Ratio}

Debt ratio or so-called debt to total assets is included in the ratio of solvency. Syamsuddin (2004) said that the debt ratio is used to measure how much the total assets of the company financed by total debt. If the total debt is greater then the higher the financial ratios, otherwise if the debt ratio is smaller then the debt owned by the company will also be smaller. Thus, the company's financial risk return on loans will also be smaller. When viewed from the shareholders, a high ratio will result in high interest payments and will ultimately reduce dividend payouts (Darsono, 2005).

Hypothesis 2: Debt ratio can predict financial distress.

\section{Return on Equity Ratio}

Return on equity is included in profitability ratio. Horne and Wachowicz (2012) says that the return on equity ratio compares net income after tax with equity invested by the company's shareholders. This ratio shows the power to generate return on investment based on the shareholder value of books and is often used in comparing two or more companies for good investment opportunities and cost-effective management. Fahmi (2012) says that the return on equity ratio is the ratio used to examine the extent to which a company uses the resources it has to generate.

Hypothesis 3: Return of equity ratio can predict financial distress.

\section{Capitalization Ratio}

Capitalization ratio is called the capital structure ratio. Rodoni and Ali (2010) says that the capital structure is the proportion in determining the fulfillment of corporate spending where the funds obtained using a combination or combination of sources derived from longterm funds consisting of two main sources namely from inside and outside company. Sartono (2010) said that the capital structure is a balance of the amount of short-term debt is permanent, long-term debt, preferred stock and common stock. Based on the above theoretical study, it can be formulated hypothesis as follows:

Hypothesis 4: Capitalization ratio can predict financial distress. 


\section{RESEARCH METHOD}

The research design used is quantitative research which is associative causal. One type of systematic, well-planned, and clearly structured research in the design of research is quantitative research. Sugiyono (2010) said that quantitative research to see the relationship of variables to the object under study and more causal, so in his research there are independent variables and dependent variables. Sangadji \& Sopiah (2010) say that associative research (relationship) is a study whose purpose is to know the relationship between two or more variables. The purpose of associative research is to see whether there is influence and the influence of the cause or effect of independent variables on the dependent variable in the study.

The number of data samples used are 34 property and real estate companies listed on the Indonesia Stock Exchange. Sample data obtained as many as 170 financial statements. A total of 11 financial statements can not be used to be sampled because there are outliers. Then the data that can be used only 159 financial statements.

Financial distress is a dependent variable. Financial distress is the condition of a company that can not pay its liabilities to creditors caused by financial difficulties that are too prolonged. Altman Z-score (bankruptcy model) is used as a tool to measure the financial status of a company experiencing financial difficulties (Ramadhani, Suci, \& Lukviarman, 2009). In a non-manufacturing company, the formula used consists of 4 coefficients, namely:

$$
\mathrm{Z}=6,56 \mathrm{~T}_{1}+3,26 \mathrm{~T}_{2}+6,72 \mathrm{~T}_{3}+1,05 \mathrm{~T}_{4}
$$

With the discriminant zone as follows: When $\mathrm{Z}>2.6=$ "safe" zone, when $1.1<\mathrm{Z}<2.6=$ "gray" zone, when $\mathrm{Z}<1,1$ = "distress" zone.

The financial ratios used as independent variables, namely:

\section{Current ratio}

The ratio commonly used to analyze the working capital position of the firm is the current ratio. Current ratio is a measure showing the amount of current assets of the company to meet its short-term liabilities (Cashmere, 2012). Here is the formula of current ratio:

\section{Current ratio $=$ current assets $/$ current liabilities}

\section{Debt ratio}

Debt ratio or debt ratio is usually called the ratio of debt to total assets (total debt to total assets ratio). Debt ratio is a measure that shows the amount of debt the company used to finance the company's assets (Van \& Wachowicz, 2009). Here is the formula of debt ratio:

\section{Debt ratio $=$ total debt $/$ total asset}

\section{Return on Equity Ratio}

Return on equity ratio adalah ukuran yang menunjukkan besarnya laba yang diperoleh dari pemegang saham atas investasi yang dilakukan oleh perusahaan (Kasmir, 2012). Berikut adalah rumus dari return on equity:

\section{Return on equity ratio $=$ net income / shareholder's equity}

\section{Capitalization Ratio}


Capitalization ratio is a measure that shows the share equilibrium of a company in the fulfillment of corporate spending (Weston \& Copeland, 2001). Here is the formula of capitalization ratio:

\section{Capitalization ratio $=$ Total Debt $/$ Shareholder's Equity}

Data collection method used is purposive sampling method, that is sample collection technique with certain consideration (Sugiyono, 2014). Selected criteria, ie companies that publish their financial statements for five consecutive years in the period 2012-2016. Secondly, the Companies which only include property and real estate listed on Indonesia Stock Exchange in 2012-2016. Third, companies that have complete financial statements, especially the accounts that are used as variables in this study. The type of data used is documentary data which comes from secondary data, ie research data obtained indirectly from intermediate media (obtained or recorded by other parties). The data used are financial statements of property companies and real estate. The tool used for this test, namely Software Statistic Packing for Social Science (SPSS) version 24. To produce a good model, the results of regression analysis requires testing the classical assumption. Tests with classical assumptions are performed with the following stages:

\section{Multicolinearity test}

The multicollinearity test aims to detect whether there is any correlation between independent variables in the regression model (Ghozali, 2011). The multicollinearity test can be known by looking at tolerance values and variation inflation factor (VIF) values. The tolerance value $>0.10$ and the $\mathrm{VIF}$ value $<10$, it can be said that the independent variable does not experience multicolinearity.

\section{Heteroscedasticity test}

Heterocedasticity test aims to test whether in the regression model there is a variance inequality of the residual one observation to another observation. There are several ways that can be done to test heteroskedastisitas, namely plot test, park test, glejser test, and white test. Tests in this study using Graph Plot between the predicted value of the dependent variable is ZPRED with residual SRESID. No heteroscedasticity occurs when there is no clear pattern, and the points spread above and below the number 0 on the Y axis (Ghozali, 2011).

\section{Normality test}

Normality tests are used to test whether in a regression model, dependent variable, independent variable or both have a normal distribution or not. A good regression model is its normal or near-normal data distribution. The normality test used was Kolmogorov-Smirnov test (Ghozali, 2011). The hypothesis in this test is:

$\mathrm{H} 0=$ normal distributed data.

$\mathrm{H} 1=$ data is not normally distributed.

$* \mathrm{H} 0$ is accepted if the value of significance> 0.05 .

The technique used is multiple linear regression analysis technique. Multiple linear analysis is where the dependent variable $\mathrm{Y}$ is connected over one variable, possibly two, three, and so on to the independent variables X1, X2, X3, .., Xn but still shows a linear relationship diagram (Hasan, 2008). The significance test between independent variables to the dependent variable, either simultaneously or partially done using F statistical test and statistical test $\mathrm{t}$. 


\section{Statistical test F (Simultaneous)}

F statistic test is used to test whether all independent variables or independent variables tested have a mutual influence on the dependent variable or dependent variable (Ghozali, 2011). To determine the F-table value, the significance level used is $5 \%$ with degrees of freedom $\mathrm{df}=(\mathrm{nk})$ and $(\mathrm{kl})$ where $\mathrm{n}$ is the amount of data, $\mathrm{k}$ is the number of variables including the intercept, by the test criterion, if $\mathrm{F}$ hit $>\mathrm{F}$ table $(\mathrm{a} ; \mathrm{kl}$; nk), then $\mathrm{H} 0$ is rejected but if $\mathrm{F}$ hit $<\mathrm{F}$ table (a; ka; $\mathrm{nk}$ ), then $\mathrm{H} 0$ is accepted.

\section{Statistical test $\mathbf{t}$}

Statistical test $t$ is done to find out how far the influence of a partial independent variable in explaining the variation of dependent variable (Ghozali, 2011). The effect of independent variables on the dependent variable individually can be tested by t-test where the significant level used is $5 \%$ or 0.05 . If the significant value of an independent variable $<0.05$ then the variable affects the dependent variable.

\section{Coefficient of determination}

To see the contribution of the ability to explain the independent variables simultaneously to the variances of the dependent variable can be seen from the coefficient of determination $\left(\mathrm{R}^{2}\right)$ in which the coefficient value between $0 \leq 1$. This means that $R 2$ is approaching 1 is an indicator that shows the stronger ability to explain change of independent variable to dependent variable.

\section{RESULTS AND DISCUSSION}

Table 1. Descriptive Statistics

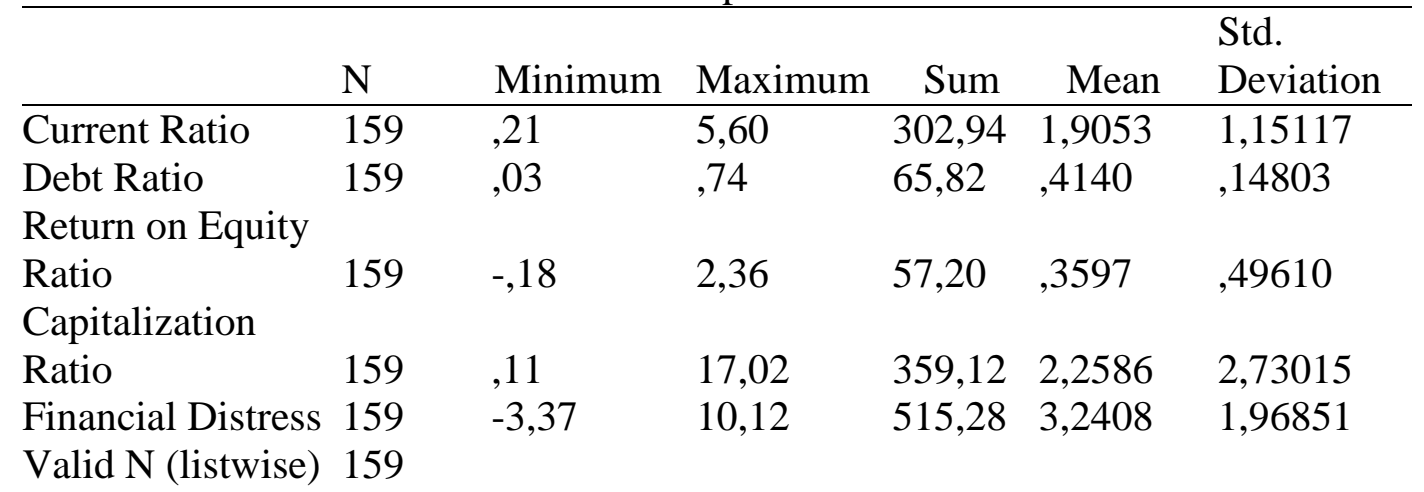

Table 1 above shows data totaling 159 data. There are 4 independent variables and 1 dependent variable. In the first independent variables seen the average count (current) ratio (X1) during the observation period of 1.9053 with a standard deviation of 1.15117 where the standard deviation value is smaller than the average value. A small standard deviation indicates a small variable current ratio gap. The smaller the standard deviation the lower the spread of observational data and its variability. The same thing also happened to the debt ratio (X2) which has the average count (mean) of 0.4140 with the standard deviation of 0.14803 where the standard deviation value is less than the average value. A small standard deviation indicates a small debt ratio gap. The smaller the standard deviation the lower the spread of observational data and its variability. The same thing happened to the financial distress (Y) which has the average count (mean) of 3.2408 with the standard deviation of 1.96851 where the standard deviation value is smaller than the average value. A small 
standard deviation indicates a small variable financial distress gap. The smaller the standard deviation the lower the spread of observational data and its variability. While the average count (mean) return on equity ratio (X3) during the observation period of 0.3597 with a standard deviation of 0.49610 where the standard deviation value is greater than the average value. Standard deviations greater than the mean indicate a large gap of return on equity variables. The larger the standard deviation the more the spread of observation data and has the tendency of each data is different or have high variability. The same is true of the capitalization ratio (X4) which has a mean of 2.2586 with a standard deviation of 2.73015 where the standard deviation value is greater than the average value. Standard deviations greater than the mean indicate a large gap of variable capitalization. The larger the standard deviation the more the spread of observation data and has the tendency of each data is different or have high variability.

\section{Multicolinearity Test}

Table 2. Coefficients of Multicolinearity Test

\begin{tabular}{clcc}
\hline Model & & Collinearity & Statistics \\
\hline \multirow{2}{*}{1} & (Constant) & Tolerance & VIF \\
& Current Ratio &, 875 & 1,142 \\
& Debt Ratio &, 528 & 1,896 \\
& Return on Equity &, 363 & 2,755 \\
& Ratio & & \\
& Capitalization Ratio &, 256 & 3,907 \\
\hline
\end{tabular}

Table 2 shows that based on tolerance values, independent variables show a value greater than 0.10 and based on its VIF value indicates a value less than 10 so it can be concluded that the four independent variables have no multicollinearity relationship and can be used to predict financial distress.

\section{Heteroscedasticity Test}

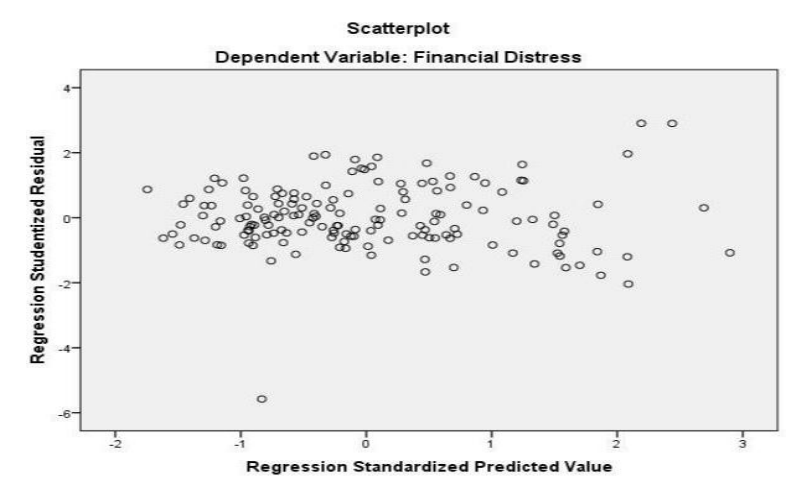

Figure 1. Scatterplot 


\section{Normality Test}

Table 3. One-Sample Kolmogorov-Smirnov Test

\begin{tabular}{lll}
\hline & & $\begin{array}{l}\text { Unstandardized } \\
\text { Residual }\end{array}$ \\
\hline $\mathrm{N}$ & & 159 \\
Normal & & \\
Parametersa,b & Mean &, 0000000 \\
Std. Deviation &, 92542904 \\
Most Extreme & Absolute &, 069 \\
Differences & Positive &, 066 \\
& Negative &,- 069 \\
Test Statistic & &, 069 \\
Asymp. Sig. (2-tailed) & &, 059 \\
\hline
\end{tabular}

Table 3 seen Kolmogorov-Smirnov value of 0.069 and significance of 0.059 above 0.05 . Thus, it can be interpreted that the data used is normally distributed.

\section{Multiple Linear Regression Analysis}

From the table above can be prepared multiple linear regression equation:

$$
\mathrm{Y}=3,737+0,999 \mathrm{X} 1-6,509 \mathrm{X} 2+0,893 \mathrm{X} 3-0,012 \mathrm{X} 4
$$

Tabel 4. Coefficients of Multiple Linear Regression Equation

\section{Coefficients}

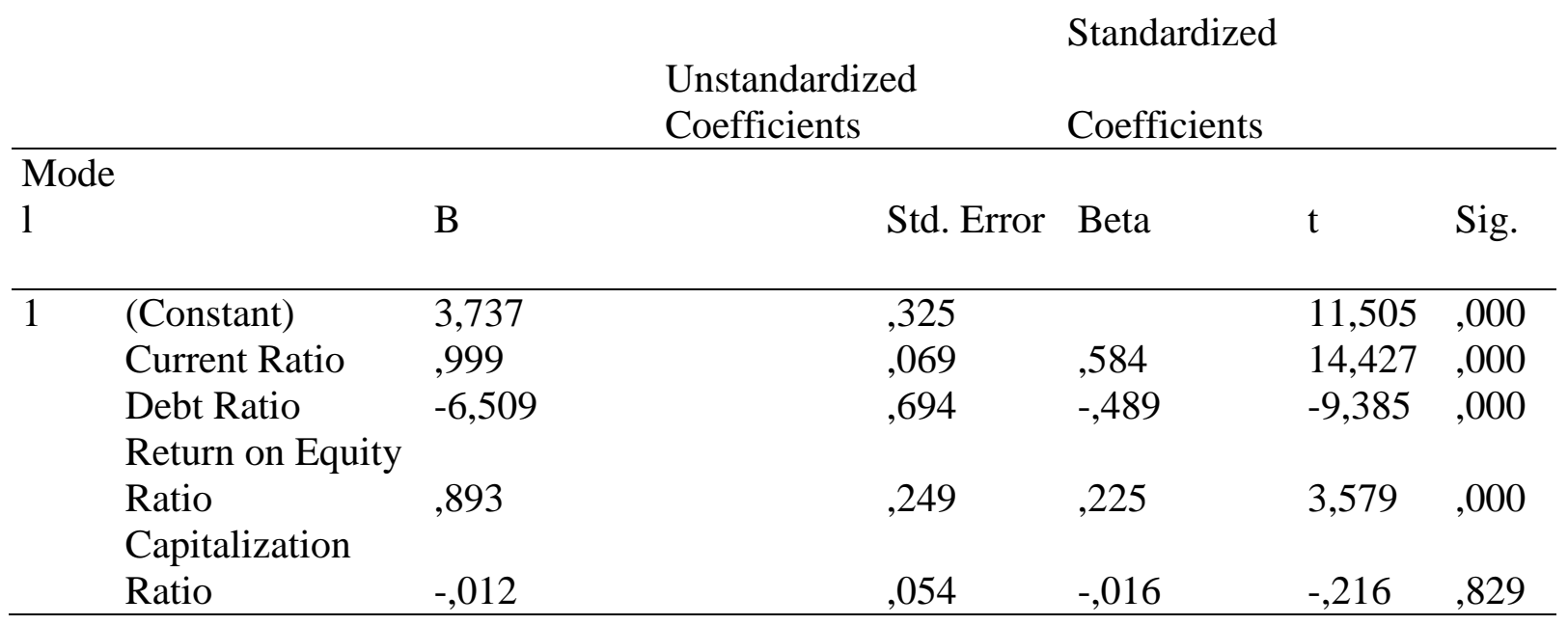

The Formula:

$\mathrm{Y}=$ financial distress, $\mathrm{X}_{1}=$ current ratio, $\mathrm{X}_{2}=$ debt ratio, $\mathrm{X}_{3}=$ return on equity ratio, $\mathrm{X}_{4}=$ capitalization ratio.

Based on table 4 the coefficients of multiple linear regression equation above can be interpreted that the value of contense (a) generated amounted to 3.737 have meaning if the financial ratio equal to zero then the financial distress is positive value of 3.737. Second, the current ratio coefficient ratio of 0.999 means any increase in current ratio of 1 unit will have a positive effect on financial distress of 0.999 units. Third, the regression coefficient of debt 
ratio of $-6,509$ means any increase of debt ratio of 1 unit will negatively affect the financial distress of 6,509 units. Fourth, the regression coefficient of return on equity ratio of 0.893 means any increase of return on equity ratio of 1 unit will have a positive effect on financial distress of 0.893 units and the fifth, the coefficient of regression capitalization ratio of -0.012 means any increase of capitalization ratio of 1 unit will negatively affect the financial distress of 0.012 units.

\section{Test Statistic F (Simultaneous)}

Table 5. ANOVA

\begin{tabular}{lllllll}
\hline Model & & $\begin{array}{l}\text { Sum of } \\
\text { Squares }\end{array}$ & df & $\begin{array}{l}\text { Mean } \\
\text { Square }\end{array}$ & F & Sig. \\
\hline \multirow{2}{*}{1} & Regression & 476,940 & 4 & 119,235 & 0 &, $000 \mathrm{~b}$ \\
& Residual & 135,314 & 154 &, 879 & & \\
& Total & 612,254 & 158 & & & \\
\hline
\end{tabular}

Table 5 obtained F-count value of 135,700 with a confidence $a=0.05(5 \%)$ which means probability $>\mathrm{a}=5 \%$. The F-count value of 135,700 is much larger than the F-table value of 2.43. Concluded $\mathrm{HO}$ rejected and $\mathrm{Ha}$ accepted which means that the independent variable, namely: current ratio, debt ratio, return on equity ratio, capitalization ratio have significant effect simultaneously to dependent variable, that is financial distress and inform that research model was fit.

\section{Test Statistic t (Partial)}

Table 6. Coefficients of Test Statistic t (Partial)

\begin{tabular}{|c|c|c|c|c|c|c|}
\hline & & & & Standardized & & \\
\hline & & Unstanc & zed & & & \\
\hline & & Coeffic & & Coefficients & & \\
\hline & & & Std. & & & \\
\hline \multicolumn{2}{|l|}{ Model } & B & Error & Beta & $\mathrm{t}$ & Sig. \\
\hline \multirow[t]{7}{*}{1} & (Constant) & 3,737 & ,325 & & 11,505 & ,000 \\
\hline & Current Ratio & ,999 & ,069 &, 584 & 14,427 & 000 \\
\hline & Debt Ratio & $-6,509$ & 694 &,- 489 & $-9,385$ & ,000 \\
\hline & Return on Equity & & & & & \\
\hline & Ratio & 893 & 249 & ,225 & 3,579 & ,000 \\
\hline & Capitalization & & & & & \\
\hline & Ratio &,- 012 & ,054 &,- 016 &,- 216 & ,829 \\
\hline
\end{tabular}

\section{Interpretation of Variable Current Ratio Analysis}

Table 6 has a significant value of 0.000 which is smaller than the level of significance 0.05 . It can be concluded that current ratio can predict financial distress. This result is contrary to research conducted by Fitriyah \& Haryati (2013). Current ratio can predict financial distress because if the current assets of the property and real estate company is not sufficient to pay off the short-term obligations of the company, then the company will experience financial difficulties that may affect the company's operational activities. 


\section{Interpretation of Variable Debt Ratio Analysis}

Table 6 has a significant value of 0.000 which is smaller than the level of significance 0.05 . It can be concluded that debt ratio can predict financial distress. The results of this test are supported by Kumalaningrum research (2015) where the debt ratio has a positive and significant effect on financial distress. Debt ratio can predict financial distress because this ratio shows the amount of total debt to the total total assets owned by the company where the company must have enough assets to pay its debts. If the total debt is greater than the total assets held by the company as the sustainable, then the company will gradually experience financial difficulties.

\section{Interpretation of Variable Analysis Return on Equity Ratio}

Table 6 has a significant value of 0.000 which is smaller than the level of significance 0.05 . It can be concluded that the return on equity ratio can predict financial distress. The result of this test is supported by Widati \& Pratama (2015) research where the return on equity ratio has positive and significant effect on financial distress. Return on equity ratio can predict financial distress because if a company can not generate profit for investors, investor's interest to invest will decrease and cause decrease of company fund in developing company.

\section{Interpretation of Variable Capitalization Ratio Analysis}

Table 6 has a significant value of 0.829 which is greater than the 0.05 level of significance. It can be concluded that capitalization ratio or capital structure can not predict financial distress because big or small debt owned by company does not influence external party (investor) in assisting development of company activity, hence less possibility for the occurrence of financial difficulties.

\section{Coefficient of Determination}

Tabel 7. Coefficient of Determination

\begin{tabular}{ccccc}
\hline \multicolumn{5}{c}{ Model Summary } \\
\hline Model & $\mathrm{R}$ & $\mathrm{R}$ Square & $\begin{array}{c}\text { Adjusted R } \\
\text { Square }\end{array}$ & $\begin{array}{c}\text { Std. Error of } \\
\text { the estimate } \\
1\end{array}$ \\
&, $833 \mathrm{a}$ &, 779 &, 773 &, 93737 \\
\hline
\end{tabular}

In table 7 the results of determination coefficient test $\left(\mathrm{R}^{2}\right)$ of 0.779 or $77.9 \%$ of the dependent variable (financial distress) is influenced by the independent variable (current ratio, debt ratio, return on equity ratio, capitalization ratio) and equal to 0.221 or $22,1 \%$ is influenced by other factors not discussed.

\section{CONCLUSION}

The results of the above test can be concluded that the current ratio of the company is in a sustainable, then the company will gradually experience financial difficulties. Second, the debt ratio can predict financial distress where if the total debt is greater than the total assets held by the company as the sustainable, then the company will gradually experience financial difficulties. Third, the return on equity ratio can predict financial distress where if the income by the company is small, the investor's interest to invest the financial condition company in carrying out its activities. Fourth, the capitalization ratio is not supported to predict financial 
distress where the large or small total debt owned by the company will not affect the investor's interest to invest as long as the company can still provide the appropriate returns to the investors. Limitations in this study are only quantitative in which using independent variables consisting of only four variables, namely current ratio, debt ratio, return on equity ratio, capitalization ratio. Secondly, only take samples within five years on property and real estate companies listed on the Indonesia Stock Exchange. Third, using only Altman Z-Score method to predict financial distress and fourth, there are some outliers so that the data used for this research is reduced. For further research may consider also qualitative aspects such as economic factors, social, technology, and changes in government regulations that cause bankruptcy of a company and from the use of observation period should conduct research with a longer period. Furthermore, it should not only use the Altman Z-Score method in predicting financial distress, but can use the Springate S-Score and Zmijewski X-Score methods to compare accuracy in predicting financial distress.

\section{REFERENCES}

Almansour, B. (2015). Empirical Model for Predicting Financial Failure. American Journal of Economics, Finance, and Management, 113-124.

Altman, E. (1968). Financial Ratios, Discriminant Analysis, and the Prediction of Corporate Bankruptcy. The Journal of Finance, 589-609.

Atika, Darminto, \& Handayani, S. R. (2013). Pengaruh Beberapa Rasio Keuangan Terhadap Prediksi Kondisi Financial Distress. Jurnal Administrasi Bisnis.

Darsono, A. (2005). Pedoman Praktis Memahami Laporan Keuangan. Yogyakarta: ANDI.

Desmanto, B. (2016). Influence Of Financial Ratios To Financial Distress Prediction Manufacturing Companies Listed On The Indonesian Stock Exchange. Jakarta: Bayu Desmanto.

Dewi, A. S., \& Wirajaya, A. (2013). Pengaruh Struktur Modal, Profitabilitas dan Ukuran Perusahaan pada Nilai Perusahaan. E-jurnal Akuntansi Universitas Udayana, 358-372.

Edwards, D. J., Baiden, B., Owusu-Manu, D.-G., Badu, E., \& Love, P. E. (2017). Financial distress and highway infrastructure delays. Journal of Engineering, Design and Technology, 118-132.

Errossa, P. L. (2013). Pengaruh Current Ratio Dan Total Debt To Total Assets Terhadap Net Profit Margin Pada Perusahaan Food and Beverage Yang Terdaftar Di Bursa Efek Indonesia Periode 2008-2012. Bandung: Fakultas Bisnis Dan Manajemen Universitas Widyatama.

Fahmi, I. (2012). Analisis Laporan Keuangan. Bandung: Alfabeta.

Fitriyah, I., \& Haryati. (2013). Pengaruh Rasio Keuangan Terhadap Financial Distress Pada Perusahaan Properti Dan Real Estate. Jurnal Ilmu Manajemen, 760-772.

Fitriyah, I., \& Haryati. (2013). Pengaruh Rasio Keuangan Terhadap Financial Distress Pada Perusahaan Properti Dan Real Estate. Jurnal Ilmu Manajemen, 769.

Gejali, I. A. (2013). Pengaruh Current Ratio, Return on Equity, dan Earning per Share terhadap Return Saham. Jurnal Ilmu \& Riset Manajemen.

Ghozali, I. (2011). Aplikasi Analisis Multivariate Dengan Program SPSS. Semarang: Badan Penerbit Universitas Diponegoro.

Hanafi, M. H., \& Halim, A. (2007). Analisis Laporan Keuangan. Yogyakarta: UPP STIM YKPN.

Hapsari, E. I. (2012). Kekuatan Rasio Keuangan dalam Memprediksi Kondisi Financial Distress Perusahaan Manufaktur yang terdaftar di BEI. Jurnal Dinamika Akuntansi. 
Harahap, S., \& Sofyan. (2008). Analisa Kritis atas Laporan Keuangan. Jakarta: PT. Raja Grafindo Persada.

Hasan, M. I. (2008). Pokok-Pokok Materi Statistik 1 (Statistik Deskriptif). Jakarta: Bumi Aksara.

Hery. (2016). Analisis Laporan Keuangan. Jakarta: PT. Grasindo.

Horne, V., C., J., \& Wachowicz, M. J. (2012). Prinsip-Prinsip Manajemen Keuangan. Jakarta: IAI. (2002). Standard Akuntansi Keuangan. Jakarta: Salemba Empat.

Julita. (2010). Pengaruh Debt to Equity Ratio dan Debt to Assets Ratio terhadap Profitabilitas Pada Perusahaan Transformasi yang terdaftar di Bursa Efek Indonesia. Jurnal Dosen Ekonomikawan - Ganjil 2010.

Juniarsi, A. T., \& Suwarno, A. E. (2005). Rasio Keuangan Sebagai Prediksi Kegagalan Pada Bank Umum Swasta Nasional Non Devisa di Indonesia. Jurnal Akuntansi dan Keuangan.

Kasmir. (2012). Analisis Laporan Keuangan. Jakarta: PT. Raja Grafindo Persada.

Kumalaningrum, B. (2015). Analisis Pengaruh Rasio Keuangan Dalam Prediksi Financial Distress Pada Perusahaan Manufaktur Yang Terdaftar Di Bei Pada Tahun 2010 - 2013. Surakarta: Fakultas Ekonomi Dan Bisnis Program Studi Akuntansi Universitas Muhammadiyah Surakarta

Kurniasari, C. (2013). Analisis Pengaruh Rasio Camel dalam Memprediksi Financial Distress Perbankan Indonesia. Semarang: Fakultas Ekonomika dan Bisnis Universitas Diponegoro.

Modigliani, \& Miller. (1963). Corporate Income Taxes on the Cost of Capital: A Correction. American Economic Review, 53.

Munawir, S. (2007). Analisa Laporan Keuangan. Yogyakarta: Liberty.

Ramadhani, Suci, A., \& Lukviarman, N. (2009). Perbandingan analisis prediksi kebangkrutan menggunakan Model Altman pertama, Altman revisi, dan altman modifikasi dengan ukuran dan umur perusahaan sebagai variabel penjelas (studi pada perusahaan manufaktur yang terdaftar di Bursa Efek Indonesia). Jurnal Siasat Bisnis, 15-28.

Rodoni, A., \& Ali, H. (2010). Manajemen Keuangan. Jakarta: Mitra Wacana Media.

Sangadji, E. M., \& Sopiah. (2010). Metodologi Penelitian Pendekatan Praktis dalam Penelitian. Yogyakarta: ANDI

Sartono, A. (2010). Manajemen Keuangan Teori dan Aplikasi.

Munawir, S. (2010). Analisa Laporan Keuangan. Yogyakarta: Liberty.

Sawir, A. (2003). Analisis Kinerja Keuangan dan Perencanaan Keuangan. Jakarta: PT Gramedia Pustaka Utama.

Sekaran, U. (2006). Metodologi Penelitian untuk Bisnis. Jakarta: Salemba Empat.

Sugiyono. (2009). Metode Penelitian Kuantitatif, Kualitatif dan R\&D. Bandung: Alfabeta.

Sugiyono. (2010). Metode Penelitian Pendidikan Pendekatan Kuantitatif, Kualitatif, dan $R \& D$. Bandung: Alfabeta.

Sugiyono. (2014). Metode Penelitian Kuantitatif, Kualitatif, dan Kombinasi (Mixed Methods). Bandung: Alfabeta.

Sutrisno. (2012). Manajemen Keuangan Teori, Konsep dan Aplikasi. Yogyakarta: Ekonisia.

Syamsuddin. (2004). Manajemen Keuangan Perusahaan. Jakarta: PT. Raja Grafindo Persada.

Van, H. J., \& Wachowicz, J. M. (2009). In D. Fitriasari, \& D. A. Kwary, Prinsip-Prinsip Manajemen Keuangan. Jakarta: Salemba Empat.

Weston, J. F., \& Copeland, T. E. (2001). Manajemen Keuangan. Jakarta: Erlangga.

Wibowo , H. A., \& Pujiati , D. (2011). Analisis Rasio Keuangan Dalam Memprediksi Perubahan Laba Pada Perusahaan Real Estate Dan Properti Di Bursa Efek Indonesia (BEI) dan Singapura (Sgx). Surabaya: The Indonesian Accounting Review.

Widarjo, W., \& Setiawan, D. (2009). Pengaruh Rasio Keuangan Terhadap Kondisi Financial 
Distress Perusahaan Otomotif. Jurnal Bisnis dan Akuntansi

Widati, L. W., \& Pratama, B. A. (2015). Pengaruh Current Ratio, Debt to Equity Ratio, dan Return on Equity untuk Memprediksi Kondisi Financial Distress.

Yusralaini, A., \& Helen, I. (2009). Pengaruh Perputaran Modal Kerja, Struktur Modal, Umur Perusahaan, dan Ukuran Perusahaan terhadap Profitabilitas pada Perusahaan Automotive and Allied Product di Bursa Efek Jakarta. Jurnal Ekonomi. 